\title{
ASPHODELACEAE
}

IODRELLIA FISTULOSA, A NEW GENERIC RECORD FOR THE FLORA OF SOUTHERN AFRICA REGION

Jodrellia Baijnath, described in 1978 (Baijnath 1978), is a small genus of about three species. Currently it is regarded as having an uncertain generic circumscription (Kativu 1996). It was initially segregated from Bulhine Wolf on the basis of tepal nervation and relative width: in Bulbine they are I-nerved, whereas in Jodrellia the inner ones are 1-nerved and the outer ones 3-5-nerved: in Bulbine the inner ones are wider than the outer, whereas in Jodrellia the reverse occurs (Baijnath 1978). Recent DNA studies have shown that Jodrellia may in fact be related to Trachyandra Kunth rather than Bulbine (Baijath pers. comm., cited by Kativu 1996).
The new record is from the extreme eastern part of the Caprivi Strip, Namibia, botanically a poorly known area of the Flora of southern Africa region. It matches well the PRE specimens of Jodrellia fistulosa (Chiov.) Baijnath from Tanzania, Zimbabwe and Zambia, which have noninflated fruits. The type, Chiovenda 557 , is from the apparently disjunct northern Ethiopian/Eritrean populations. This specimen is in poor condition and it is impossible to decide whether the fruits are mature, and if not, whether they would be inflated at maturity. There is thus a possibility that the southern populations may represent a distinct entity. Kativu (1996) provides a distribution map of Jodrellia fistulosa for the Flora zambesiaca area. 


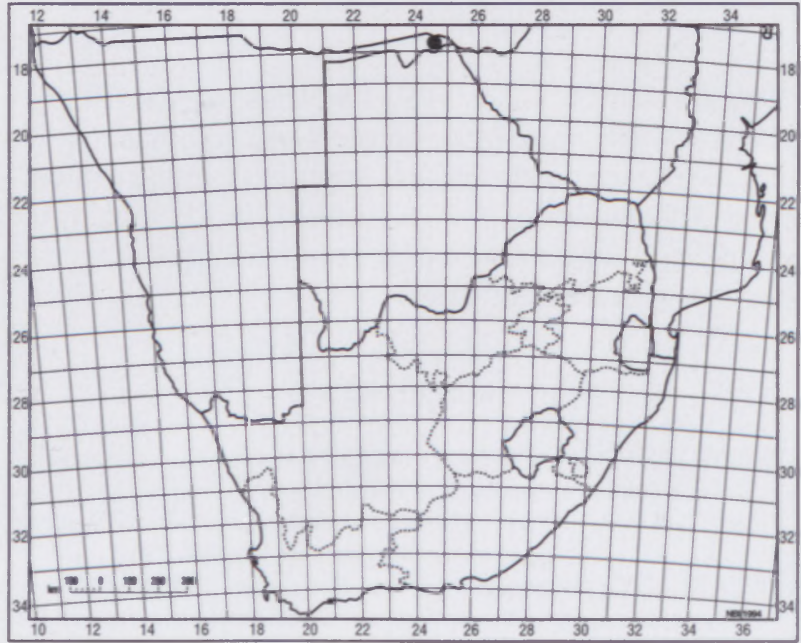

FIGURE 7.-Distribution of Jodrellia fistulosa (Chiov.) Baijnath in southern Africa.
The new locality (Figure 7) is not very far from the westernmost record cited by Kativu (1996), i.e. Machili, Zambia $\left(16^{\circ} 51^{\prime} \mathrm{S} ; 25^{\circ} 07 \mathrm{E}\right)$. The habitat is fairly typical for the species, i.e. Colophospermum mopane (Benth.) J.Léonard woodland, in sandy soil.

\section{Specimen examined}

NAMIBIA.-1724 (Katima Mulilo): 29 km SE of Katima Mulilo on Ngome road, (-DA), Venter, Hahn \& Archer 128 (PRE, WIND).

\section{REFERENCES}

BAIJNATH, H. 1978. Jodrellia, a new genus of Liliaceae from tropical Africa. Kew Bulletin 32: 571-578.

KATIVU, S. 1996. Asphodelaceae of the Flora zambesiaca area. Kirkia 16: 27-53.

C. ARCHER*

* National Botanical Institute, Private Bag X101, 0001 Pretoria. MS. received: 2000-08-08. 